\title{
Career planning and mentorship: a few key considerations for trainees
}

This article was published in the following Dove Press journal:

International Journal of General Medicine

II October 2017

Number of times this article has been viewed

\author{
Sherif M Badawy ${ }^{1-3}$ \\ 'Division of Hematology, Oncology \\ and Stem Cell Transplant, Ann \& \\ Robert H. Lurie Children's \\ Hospital of Chicago, Chicago, IL, \\ USA; ${ }^{2}$ Department of Pediatrics, \\ Northwestern University Feinberg \\ School of Medicine, Chicago, IL, USA; \\ ${ }^{3}$ Department of Pediatrics, Division \\ of Hematology and Oncology, Zagazig \\ University Faculty of Medicine, \\ Zagazig, Egypt
}

\begin{abstract}
Publishing and securing funding are considered our "academic currency", and therefore, both should be emphasized during training, both residency and fellowship. Trainees should make an effort to find funding opportunities at or outside of their institutions and try to identify their short- and long-term goals. Establishing a track record of publications can help trainees get hired, funded, and promoted as junior faculty, and effective networking and mentorship are critical determinants of academic success. Given the positive effects of mentorship, trainees should understand what comprises a good mentor-mentee relationship and how to optimize the mentoring process. The objective of this article is to discuss few key considerations for trainees in residency or fellowship regarding mentorship and career planning in academic medicine.
\end{abstract}

Keywords: career planning, career development, mentorship, training, fellowship, residency

\section{Introduction}

Publishing and securing funding are considered our "academic currency". ${ }^{1-3}$ After patient care, trainees should prioritize publishing and securing funding, and therefore, both should be emphasized during training, both residency and fellowship.

\section{Career planning}

Exploring many areas of multidisciplinary research early in a career can be a helpful strategy as collaborations can broaden trainees' understanding of different research methods and offer new perspectives of their own research. Trainees should identify their short- and long-term goals. This will keep them stay focused, while simultaneously helping them avoid getting "trapped" in an area outside of their objectives. For instance, many trainees take on a research project during their residency or fellowship that does not fully fit within their goals, but because it was the best option at the time, they stick with it longer than they would like to. The research project during training should be viewed as a vehicle for what comes next. What trainees learn now will help them tell their story later. The research project, during residency or fellowship, allows trainees to collect data, get funded, and get a career development award later in their research career. Therefore, it is important for trainees to find the right fit.

Establishing a track record of publications can help trainees get hired, funded, and promoted as junior faculty. ${ }^{46}$ Case reports or letters to the editor are always a good start and show trainees' commitment to their area of interest. Publishing should be an objective from the start of an academic career; if trainees do not consciously make time for it, it will not happen. Furthermore, writing quality will improve as one writes more and
Correspondence: Sherif M Badawy Hematology, Oncology and Stem Cell Transplant, Ann \& Robert H. Lurie Children's Hospital of Chicago, Feinberg School of Medicine at Northwestern University, 225 E Chicago avenue Box \#30, Chicago, IL 606II, USA

$\mathrm{Tel}+\mathrm{I} 3 / 22274789$

Fax +I 3122279373

Email sbadawy@luriechildrens.org 
it will help a trainee to refine their research focus. Trainees might not be thinking about funding so early in their career, but most institutions have a number of opportunities, such as pilot grants and seed grants, available to young researchers. These funds can be enough to begin a small project, which can lead to larger projects and more funding opportunities. Trainees should make an effort to find these opportunities at their institutions, as well as outside of their institutions.

\section{Mentorship}

Effective networking and mentorship are critical determinants of academic success. ${ }^{1,2,4,7-13}$ Trainees who have strong, committed mentors are more likely to exhibit higher research productivity, career retention, promotion, and personal development. ${ }^{4,10,11}$ Given the positive effects of mentorship, trainees should understand what comprises a good mentormentee relationship and how to optimize the mentoring process. ${ }^{8}$ Mentoring is a dynamic process and a successful mentoring relationship is a win-win situation, ${ }^{5,6,9,10,12-14}$ and different studies have shown benefits for trainees mentored by faculty as well as for peer mentoring among trainees, ${ }^{15,16}$ in particular, between fellows and residents. ${ }^{17}$ As a mentee, though, trainees should know what they want to get out of the relationship. The mentoring relationship is different for everyone, but there are a few key elements mentors and mentees should be looking for. ${ }^{12,13,18,19}$

A good mentee is always prepared, organized and proactive, has a positive and enthusiastic attitude, is interested in academic growth, expresses a willingness to learn, is receptive to critical feedback, and has a shared agenda before he/she interacts with their mentor in their scheduled meetings. ${ }^{7-9,12,13,18-20}$ Successful mentees learn from the experience of others, ask questions, and indicate when help is needed. They are willing to accept the strengths of their mentor, along with their limitations. Also, being a finisher is the key: if a trainee has committed to doing something, he/she should do it. A good mentor is patient, supportive, interested in teaching, genuinely invested in their mentee's goals, and willing to advocate for a trainee. ${ }^{7-9,12,13,18,19}$ A skilled mentor is productive, is well published, and is well funded with expertise in the trainee's area of interest, encourages open communication, provides structured learning opportunities, facilitates career and personal development, and has a good track record of mentoring others.

The actual mentoring process may be optimized by 1) identifying shared interests, goals, strengths, and needs; 2) setting ground rules and mutual expectations; 3) planning meetings with clear agendas; 4) defining goals and ways to track progress; and 5) having ongoing bidirectional feedback. At times, multiple mentors - from within or outside the institution - may be desirable to address different domains (career, research, and social/interpersonal development). ${ }^{7-9,12,13,18-20}$

In conclusion, funding, publishing, career planning, and finding a mentor are all critical - and challenging - components of starting a successful academic career, regardless of the specialty or the subspecialty. Trainees should always set aside the time to sketch out their long-term goals to be able to focus on how and why they plan for their research projects that are more likely to lead to a successful trajectory in academia.

\section{Disclosure}

The author reports no conflicts of interest in this work.

\section{References}

1. Borges NJ, Navarro AM, Grover A, Hoban JD. How, when, and why do physicians choose careers in academic medicine? A literature review. Acad Med. 2010;85(4):680-686.

2. Buddeberg-Fischer B, Stamm M, Buddeberg C. Academic career in medicine: requirements and conditions for successful advancement in Switzerland. BMC Health Serv Res. 2009;9:70.

3. Straus SE, Straus C, Tzanetos K. International Campaign to Revitalise Academic Medicine. Career choice in academic medicine: systematic review. J Gen Intern Med. 2006;21(12):1222-1229.

4. Committee on Pediatric Research. Promoting education, mentorship, and support for pediatric research. Pediatrics. 2014;133(5):943-949.

5. Beech BM, Calles-Escandon J, Hairston KG, Langdon SE, LathamSadler BA, Bell RA. Mentoring programs for underrepresented minority faculty in academic medical centers: a systematic review of the literature. Acad Med. 2013;88(4):541-549.

6. DeCastro R, Sambuco D, Ubel PA, Stewart A, Jagsi R. Mentor networks in academic medicine: moving beyond a dyadic conception of mentoring for junior faculty researchers. Acad Med. 2013;88(4):488-496.

7. Humphrey HJ. Mentoring in Academic Medicine. 1st ed. Philadelphia: Amer College of Physicians; 2010.

8. Driessen EW, Overeem K, van der Vleuten CP. Get yourself a mentor. Med Educ. 2011;45(5):438-439.

9. Kashiwagi DT, Varkey P, Cook DA. Mentoring programs for physicians in academic medicine: a systematic review. Acad Med. 2013;88(7):1029-1037.

10. Sambunjak D, Straus SE, Marusic A. Mentoring in academic medicine: a systematic review. JAMA. 2006;296(9):1103-1115.

11. Stamm M, Buddeberg-Fischer B. The impact of mentoring during postgraduate training on doctors' career success. Med Educ. 2011;45(5):488-496.

12. Omary MB. Mentoring the mentor: another tool to enhance mentorship. Gastroenterology. 2008;135(1):13-16.

13. Rustgi AK, Hecht GA. Mentorship in academic medicine. Gastroenterol. 2011;141(3):789-792.

14. Badawy SM, Black V, Meier ER, et al. Early career mentoring through the American Society of Pediatric Hematology/Oncology: lessons learned from a pilot program. Pediatr Blood Cancer. 2017;64(3).

15. Eisen S, Sukhani S, Brightwell A, Stoneham S, Long A. Peer mentoring: evaluation of a novel programme in paediatrics. Arch Dis Child. 2014;99(2):142-146.

16. Webb J, Brightwell A, Sarkar P, Rabbie R, Chakravorty I. Peer mentoring for core medical trainees: uptake and impact. Postgrad Med J. 2015;91(1074):188-192. 
17. Backes CH, Reber KM, Trittmann JK, et al. Fellows as teachers: a model to enhance pediatric resident education. Med Educ Online. 2011;16:1-9.

18. Sambunjak D, Straus SE, Marusic A. A systematic review of qualitative research on the meaning and characteristics of mentoring in academic medicine. J Gen Intern Med. 2010;25(1):72-78.
19. Straus SE, Johnson MO, Marquez C, Feldman MD. Characteristics of successful and failed mentoring relationships: a qualitative study across two academic health centers. Acad Med. 2013;88(1):82-89.

20. Zerzan JT, Hess R, Schur E, Phillips RS, Rigotti N. Making the most of mentors: a guide for mentees. Acad Med. 2009;84(1):140-144.
International Journal of General Medicine

\section{Publish your work in this journal}

The International Journal of General Medicine is an international, peer-reviewed open-access journal that focuses on general and internal medicine, pathogenesis, epidemiology, diagnosis, monitoring and treatment protocols. The journal is characterized by the rapid reporting of reviews, original research and clinical studies across all disease areas.

\section{Dovepress}

The manuscript management system is completely online and includes a very quick and fair peer-review system, which is all easy to use. Visit http://www.dovepress.com/testimonials.php to read real quotes from published authors.

Submit your manuscript here: https://www.dovepress.com/international-journal-of-general-medicine-journal 